\title{
MODERN METHODS OF GEAR MILLING \\ OF HARDENED LARGE-MODULE GEARS
}

\author{
Kateryna Kamchatna-Stepanova \\ Assistant at the Department of Engineering Technology and Metal-Cutting Tools, \\ National Technical University "Kharkiv Polytechnic Institute", Ukraine \\ e-mail: katerina.ks@i.ua,orcid.org/0000-0001-7825-1238
}

\section{Oleksandr Klochko}

Doctor of Technical Sciences,

Professor at the Department of Engineering Technology and Metal-Cutting Tools, National Technical University "Kharkiv Polytechnic Institute", Ukraine e-mail: ukrstanko21@ukr.net, orcid.org/0000-0003-2841-9455

\section{Summary}

The latest developments of modern methods of high-speed gear milling of large-module cylindrical gears, both for preliminary grinding of teeth and for final blade processing of gears, are considered. For high-speed blade gear processing, promising designs of worm carbide cutters have been developed, manufactured and implemented. The technological regulations of blade gear processing for the operation of each of the design solutions of worm carbide cutters have been developed. The design of a special double-body worm cutter for double-sided cutting has been developed. It is shown that the carbide cutting elements of the milling cutters, which are placed only along the lines of the machine engagement of the tool and the workpiece, make it more economical compared to the known designs of similar tools. The application of the developed technological methods of pre-blade processing of the teeth of hardened wheels with carbide cutters reduces the labor intensity of low-performance gear grinding operations, depending on the wheel module, by 3-4 times by reducing the allowance from 1.5-2.5 mm on the tooth side to $0.3-0.5 \mathrm{~mm}$, and also allows you to ensure the gear processing process is economical by reducing the consumption of carbide plates. The developed technological studies of ensuring the quality of gear processing of large-module cylindrical wheels allow us to solve the scientific and technical problem associated with the production of large-module gears with high-hardness teeth while improving the quality of their manufacture, reducing labor costs and reducing material consumption.

Keywords: high-speed blade gear processing, carbide cutters, cutting elements, technological methods, surface layer quality.

DOI https://doi.org/10.23856/4340

\section{Introduction}

The increase in production efficiency in various industries is largely due to the development and development of mining and processing equipment, transport and energy systems, and other large-sized machines whose drives include large-module gears $(m>12 \mathrm{~mm})$. The improvement of the specified technological equipment consists in increasing its power, increasing the speed of mutual movement of elements, ensuring the reliability of operation in deteriorating dynamic conditions, increasing durability (Czerniec, M., 2019: 53). 
The scientific novelty of the obtained results is that on the basis of a broad analysis and generalization of industrial achievements in gear processing, requirements for heavy-loaded and responsible gears, general principles for the development of structures and parameters of technological systems for gear processing of hardened large-module gears are formulated and implemented for the first time. This allows you to intensify the processing process and increase the efficiency of the process by minimizing the wear rate of the cutting tool and the cost of manufacturing it, provided that high accuracy of engagement and the quality of the surface layer are obtained.

The relevance of scientific solutions is to increase the productivity, accuracy and quality of gear processing of hardened large-modular gears on the basis of improving the technological system and kinematics of gear milling, the design of tool and technological equipment. This allows you to increase the efficiency of shaping while ensuring the required accuracy of the gears. The development of a scientifically based assessment system allows technological support of the operational properties of the contact surfaces of hardened large-modular gears.

The purpose of the study is to solve the main directions of ensuring high performance of gear processing of hardened large-module gears at the specified parameters of accuracy and quality. To achieve this goal, it was necessary to solve research tasks to justify the development of a system of objective criteria for evaluating technological solutions that characterize the processing object, the technological process of shaping and allow us to formulate the main directions for ensuring high performance of gear processing of hardened large-module gears with specified parameters of accuracy and quality of the surface layer after processing.

The methodological basis of the work is a systematic approach to the study and description of the object and subject of research and, first of all, the technological processes of shaping the gear processing of hardened large-module gears as the basis for the formation of the principles of production system management, the principles of modeling and management of the structure and parameters of discrete technological systems. Theoretical research is based on the basic principles of mechanical engineering technology, the theory of similarity and dimensions, the theory of simulation modeling, and the theory of artificial intelligence. Methods of pattern recognition theory and vector algebra are used for mathematical modeling of the structure of the production system. The theory of algorithms and the principles of structural object-oriented programming, as well as methods of discrete optimization, were used to create a software and methodological complex of the production system simulation system. Group theory and relationship theory were used to analyze the structural properties of technological operations. The formalization of technological solutions was carried out on the basis of production models of knowledge representation. Experimental studies were conducted using the theory of modeling, discrete and correlation analysis.

\section{Technological methods of processing large-module gears}

The creation of new equipment in some cases is constrained by the technological capabilities of manufacturing gear drives. Increasing the hardness of the working surfaces of the teeth of gears is one of the most effective and relevant ways to increase the load capacity and durability of gears and, consequently, gearboxes while reducing their size and weight (Alaa, F., 2017; Dhafer, W., 2016: 45).

The results of a number of studies (Kostyk, K., 2016: 54; Nechyporuk, M., 2020) indicate that increasing the surface hardness of the teeth from HRC 30 to HRC 60 allows you to halve the dimensions of the gearbox and reduce its weight by 3 times (Gołębski, R., 2018: 645). 
Modern technology of gear processing of large-modulus hardened wheels is developing in the direction of developing new technological approaches (Klochko, A., 2020: 25; Kostyk, V., 2019), forming processes of working surfaces of teeth (Gotębski, R., 2018: 647), creating new high-performance equipment (Mironenko, E., 2013: 3; Mironenko, E., 2015: 28), new tool materials and tools (Mohammadkhani, R., 2012: 6685).

Modern requirements for increasing the hardness of the working surfaces of the teeth of gears is one of the most effective and relevant directions for increasing the load capacity and durability (Kostyuk, G., 2019: 27) of gears and gearboxes while reducing their size (Jian, K., 2013: 4780; Suslov, A., 2006).

During the operation of the gears, rolling friction and sliding friction occur simultaneously, causing wear and destruction of the working surfaces of the teeth (Permyakov, A., 2020: 17). This is accompanied by a violation of the correct engagement, an increase in noise, a drop in efficiency, the occurrence of dynamic load, etc. (Masjedi, M., 2015: 235).

In case of excessive wear of the teeth of the gear rings $(\mathrm{m}>26)$ and the wheels of the drums $(m>20)$, it is not allowed to leave them in the mechanisms. The amount of wear and tear must not exceed the standard value by more than $0,17 \mathrm{~m}$.

The maximum wear of the gear teeth is $(0.1-0.24) \mathrm{m}$, where $\mathrm{m}$ is the normal modulus. For gears with hardened teeth, the maximum wear is 0.8 of the cemented layer thickness. (Artoni, A., 2019: 103; Gavranovic, S., 2019: 553; Suslov, A., 2018: 3).

If the working surface of the tooth is painted and other violations of the profile exceed the permissible standards, the wheels and gears must be replaced.

At the same time, a significant increase in the hardness of gears dramatically increases the complexity of their manufacture: the requirements for the rigidity of gear-cutting equipment, tool durability, and the need for expensive, but low-performance gear-grinding machines increase.

If for gears of small and medium modulus it is possible to obtain the required gearing characteristics relatively steadily by chemical-thermal treatment and gear grinding, then for large-modulus wheels $(m=12 \div 65 \mathrm{~mm})$, especially oblique-toothed ones with a tooth angle of more than $\beta_{\mathrm{d}}=250 \div 30^{\circ}$ and a tooth length of more than $b_{\mathrm{k}}=400 \div 1200 \mathrm{~mm}$, the performance of technological operations of chemical-thermal treatment and gear grinding is repeatedly complicated, and it is not always possible to achieve the set goals due to significant thermal deformations of the teeth $(0.8-2.5 \mathrm{~mm})$ and high (more than 200 machine hours) labor intensity of gear grinding operations (Nazapov, Yu. F., 2009: 9; Shapovalov, V., 2009: 4).

Performing the technological operation of gear grinding on the teeth of a large module in the conditions of removal of an increased allowance $(1.0-2.5 \mathrm{~mm})$ leads to the appearance of such defects in the surface layer as «cauterization» and microcracks, and in the layer itself there are tensile stresses, which ultimately reduce the load capacity and durability of heavy-loaded cylindrical gears.

When assigning the parameters of the state of the contacting surfaces of cylindrical large-modulus hardened gears, the possibilities of technological processing methods for providing the parameters of the state of the surface layer of roughness ( $R \max , R a, R z, R p, S m, S$ ), undulation $(W a, W p, S m W$, ) and physical and mechanical properties of the surface layer are established $\left(k=\left(H_{\mu 0} / H_{\mu}\right) \cdot 100 \%, h_{\mu 0} \pm \sigma_{0}, h \sigma\right)$ (Timofeev, Yu. V., 2010: 214).

Analysis of the results of studies on the formation of the height of the roughness profile in various methods of gear processing of large-modulus hardened gears allowed us to conclude that the formation of roughness in all methods of gear processing by counter milling is influenced not only by the geometric parameters of the cutting part of the cutter, but also by the radius of rounding of the cutting part of the cutter. However, the effect of the rounding radius on the 
quality of the tooth surface formation during tooth processing has not been studied. The quality of the surface and the accuracy of the shape of the teeth of the wheels largely depends on the kinematic scheme of shaping, dynamic processes during gear milling, oscillatory movements of worm and special modular cutters relative to the surface to be processed.

\section{Design features of advanced designs of carbide milling cutters}

The traditional technology of processing teeth with standard worm cutters, in which the size of the cutting edges depends on the size (modulus) of the processed wheel teeth, does not allow to increase the number of cutting elements and reduce the load on the cutting edges of worm cutters, especially when equipped with hard alloy cutters. Due to the large size of the cutting edges, the process of grinding the teeth is complicated, ensuring the accuracy of the tool (Iurchyshyn, O., 2019; Stokes, J., 2008: 2).

Currently, two scientific directions of technological support of the operational properties of hardened large-module gears are being considered. The first of them provides for the technological support of the system of parameters of the surface layer (Czerniec, M., 2019; Popov, V., 2019: 471). The second is the technological support of the direct operational properties of hardened large-module gears (Kostyk, K., 2015: 39).

The foundation of the laid scientific foundations of the technology of manufacturing parts in mechanical engineering was the work of Balakshin B. S., Bazrov B. M., Granovsky G. I., Dalsky V. A., Kovan V. M., Korsakov V. S., Matalin A. A., Sokolovsky A. P., Suslov A. G., etc. (Suslov, A., 2006; Suslov, A., 2018: 8; Timofeev, Yu., 2010: 210).

When performing technological operations of tooth processing, it is time-consuming to manufacture and operate a complex tooth-processing tool. A significant increase in the hardness of the teeth of the wheels dramatically increases the complexity of their manufacture, as the requirements for the rigidity of gear cutting equipment, tool durability, there is a need for expensive, but low-performance gear grinding machines, etc. Limited processing capabilities of large-modulus gears with $m=12-65 \mathrm{~mm}$ and a tooth hardness above $350 \mathrm{HB}$ with a degree of accuracy of $7 B-8 B$ lead to the fact that in a number of branches of mechanical engineering, hardened gears are less than $20 \%$, which makes it necessary to manufacture a large number of spare parts and, accordingly, increases the labor intensity of operation, reduces the efficiency of machines.

One of the important issues of improving the reliability of hardened large-module gears is to ensure their quality indicators at the design stage of manufacturing technologies. The production of large-module gears with a tooth hardness of 52-60 HRC and a tooth length of 200-800 mm requires considerable labor. In the EU countries, the share of this stage is spent (30-35) \% of the total cost of production of the product, since up to $80 \%$ of defects are «laid» in the design of the technological process, and the quality of the product is largely determined by the condition of the contact surfaces of hardened large-module gears.

For pre-grinding of teeth or final blade processing of large-modulus cylindrical gears with a module $m=12-65 \mathrm{~mm}$, hardened 30-60 HRC, promising designs of worm carbide cutters have been developed, manufactured and implemented. For the operation of each of the design solutions of worm carbide cutters, the technological regulations for their operation have been developed (Shapovalov, V., 2009: 5; Timofeev, Yu., 2010: 211).

A special feature of the design of special double-body double-sided worm milling cutters for cutting chevron hardened gears is that a circle is used as a palloid of machine engagement of the tool and the part (Fig. 1), passing through the lower boundary points of the involute B and 
$\mathrm{B} 1$. In this case, the active sections of the gearing lines $B E$ and $B 1 E 1$ are located symmetrically relative to the inter-axial perpendicular and at some distance from it (Jian, K., 2013: 4782; Gasanov, M., 2018: 36).

The angle of the profile of the teeth of the special cutter $\alpha_{k}$ depends on the number of teeth of the processed wheel $Z_{k}$ and is determined by the dependence:

$$
\alpha_{\kappa}=\alpha_{B}-\sigma_{B},
$$

where $\alpha_{b}-$ is the angle of pressure at the lowest point $B$ of the involute; $\sigma_{b}-$ is half the angular thickness of the tooth at the lower boundary points $B$ and $B 1$ of the involute.

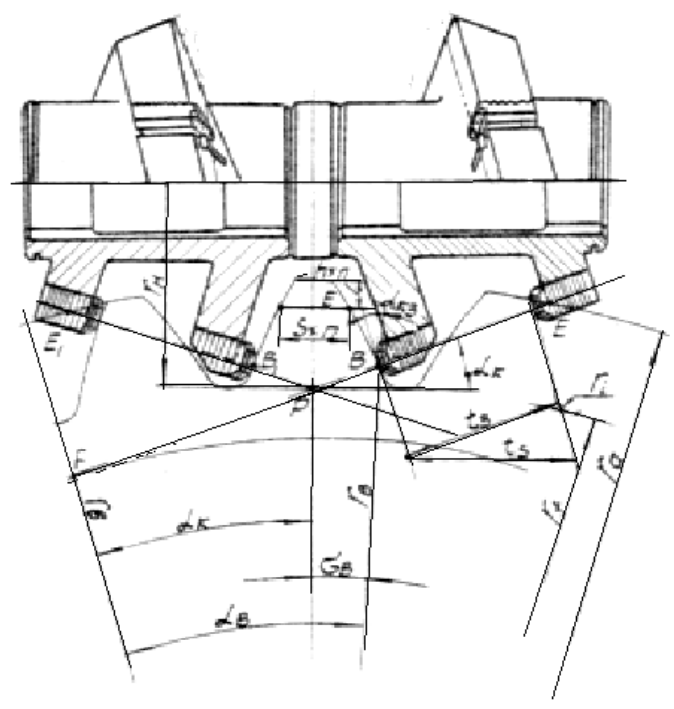

Fig. 1. Scheme of machine engagement of a special carbide milling cutter with a processed wheel

In the range of the cut teeth of the wheel $Z_{\kappa}=20-400$ the angle of the profile of the teeth of special milling cutters varies within $\alpha_{K}=5^{\circ}-19^{\circ}$.

Each cutter can cut the teeth of the wheel in a certain range of tooth numbers: $Z_{K}=33-49$, $Z_{K}=46-66, Z_{K}=60-88, Z_{K}=88-134, Z_{K}=134-204$ (Gasanov, M., 2018: 37). The technological installation of the milling cutters is achieved by turning one milling cutter body relative to the other at a certain calculated angle and changing the thickness of the remote ring laid between the housings. In each of the milling cutter bodies, several keyways are made (Mironenko, E., 2013).

Toothed uncorrected wheels with a number of teeth 33-49 can be cut with a cutter with an angle of the profile $\alpha_{\mathrm{K}}=9^{\circ}$ and the installation of the cutter bodies with a turn on the angle $\theta$ :

$$
\theta=2 z_{K} \beta_{K}
$$

where $Z_{K}$ - number of teeth of the wheel to be cut;

$$
\beta_{K}=\alpha_{K}-\alpha_{K}^{\prime},
$$

where $\alpha_{K}^{\prime}$-determined from the graph (Fig. 2). 


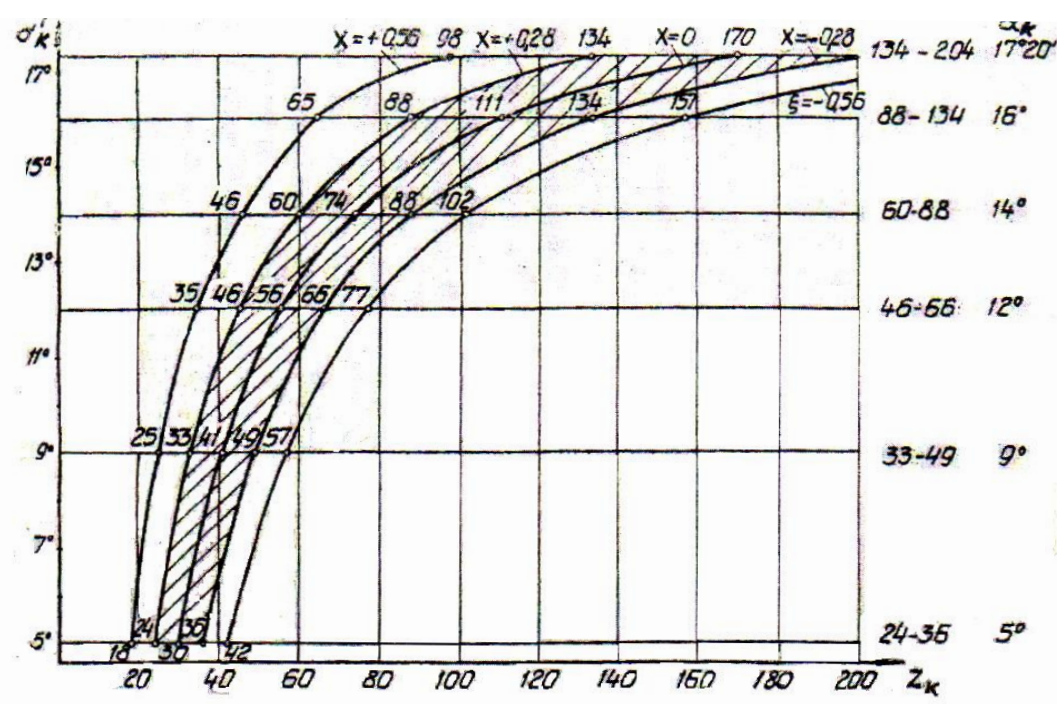

Fig. 2. Graph for determining the applicability of special carbide cutters

For corrected wheels, the range of the number of teeth to be cut increases: at $\mathrm{X}=+0.56$, applying the cutter with $\alpha_{\mathrm{K}}=9^{\circ}$, cut gears with the number of teeth 25 , and at $\mathrm{X}=-0.56$, cut gears with the number of teeth 57 (Gasanov, M., 2018: 38).

When installed on the machine, the milling cutter bodies located on the mandrel are combined with the first teeth in the same plane and set at a distance $S_{\phi}$, determined by the cone template. Measure the internal distance between the ends of both bodies of the cutter and select the remote ring on it. Then install the cutter bodies on the corresponding keyways and fix them on the mandrel. The milling cutter with a mandrel is installed in the caliper of the machine with subsequent adjustment relative to the axis of the wheel tooth.

The advantage of the considered designs of special worm cutters is that they simultaneously process both side surfaces of the wheel teeth with both housings. The cutting forces from both bodies are directed towards each other, i.e. there is a power short circuit inside the tool. This helps to reduce vibrations and vibrations of the machine table together with the processed wheel.

The most rational area of use of the considered special milling cutters is the serial and large-scale production of gears, for example, used in coal-grinding and ore-grinding mills, excavators, rolling mills, lifting mechanisms.

A special worm milling cutter (Fig. 3) $\mathrm{m=} 20 \mathrm{~mm}$ was developed and manufactured. The development of the technology of pretreatment of hardened gears with an allowance for gear grinding with worm cutters equipped with non-sharpenable rotary plates was preceded by the development and modeling of the technological process of forming using universal milling cutters $m=12-36 \mathrm{~mm}$ of one-sided and two-sided cutting, equipped with plates made of alloys VK10-OM; VK10-XOM. On the side surfaces of the turns in the tangential grooves, hard-alloy non-sharpenable rotary plates made of alloys VK10-OM; VK10-XOM with dimensions of $20 \times 16 \times 6 \mathrm{~mm}$ are installed, which are fixed in the sockets with eccentric screws.

The carbide cutting elements are placed only along the lines of the machine engagement of the tool and the workpiece, which makes such a cutter more economical compared to the known designs of similar tools. 
Also, the tangential arrangement of carbide cutting plates with wear-resistant coatings contributes to the increase in tool durability.

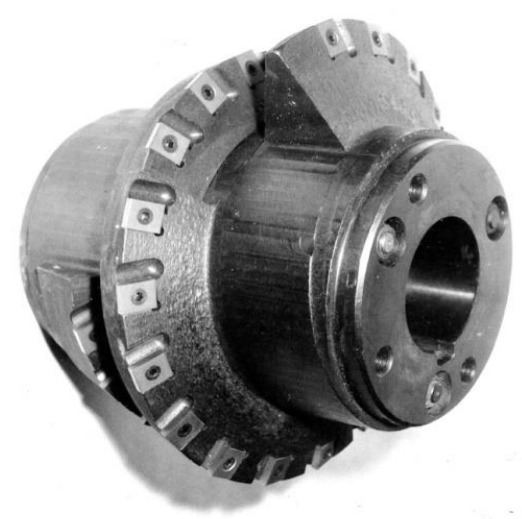

Fig. 3. Special worm carbide milling cutter $m=20 \mathrm{~mm},\left(\alpha_{u}=9^{\circ} ; z_{\kappa}=25-57\right)$

The technological disadvantage of special carbide cutters is the impossibility of processing gears with the same tool, which significantly differ from each other in the number of teeth. Meanwhile, in the practice of heavy engineering, gears that include a gear with a small number of teeth are widely used, for example, $z_{\kappa}=12 \div 40$ and a multi-toothed wheel, for example, $z_{k}=180 \div 316$. These are gears of coal-and ore-grinding mills, excavators, etc.

When processing such wheels with different worm cutters, the identity of the main pitch and the profile of the teeth will not be ensured, which will undoubtedly affect the quality of engagement and the durability of the gear train. Of particular importance for the quality of engagement is the processing of the mating pair of hardened (HRC 30-60) gears with the same tool, the operational run-in of which is practically excluded.

In order to improve the accuracy of engagement of mating, mainly hardened, gears with a different number of teeth, and to reduce the range of tools used, the design of universal large-modulus carbide worm cutters $m=12-65 \mathrm{~mm}$ has been developed. As a palloid of machine engagement of such milling cutters with the processed wheel, the dividing circle of the wheel is used, and the angle of the profile of the teeth of the tools is equal to $\alpha_{u}=20^{\circ}$.

The double-body design of single-sided cutting cutters is designed for processing wheel teeth in two passes. The milling cutter (Fig. 4) consists of the left 1 and right 2 bodies with a conical screw thread of one direction, in the grooves of which there are hard-alloy non-sharpenable rotary plates.

According to the gear processing technology developed for this design (Shapovalov, V., 2009: 3; Timofeev, Yu., 2010: 209), each of the milling cutter bodies is installed separately on the gear milling mandrel with an offset relative to the center perpendicular $00^{\prime}$ pair "tool-part" at a distance of $l_{y}$ (Fig. 4), defined by the point $B\left(B^{\prime}\right)$ of the intersection of the circle of the lower boundary point of the tooth involute and the machine engagement line $B E\left(B^{\prime} E^{\prime}\right)$. The installation distance does not depend on the number of teeth of the wheel to be processed. The value of $l_{y}$ is determined by the profile angle of the initial contour of the toothed rail $\alpha 0$, the height of the tooth leg $h_{f}$ and the radius of the rounding of the tooth head of the tool for pre-cutting $r_{\phi}$. These parameters depend only on the modulus and the displacement coefficient of the original contour of the rack. 
Thus, by alternately installing each of the housings with an offset on the gear mandrel, one cutter can process gears with any number of teeth in two passes. The displacement of the milling cutter body from the centerline perpendicular to the calculated distance $l_{y}$ is carried out using a special template installed in the center finder of the machine, which is placed on the milling head in the axis of rotation of the machine table.

For the convenience of practical determination, a graph is presented (Fig. 2) of the dependence of the installation distance $l_{y}$ on the modulus of the cut teeth of the wheel and the displacement coefficient of the initial contour of the gear rack-X. For values of the offset coefficient of the original contour $\mathrm{X}>1.0$, the value of the installation distance $l_{y}$ can be obtained with a negative sign. This means that the tool must be moved on the machine during installation so that its first tooth with the largest radius of rotation does not cross the centerline perpendicular during displacement.

In practice, the installation of the tool at the calculated distance $l_{y}$ does not require high accuracy and can be performed either using a special template or using a ruler mounted on the caliper of the machine.

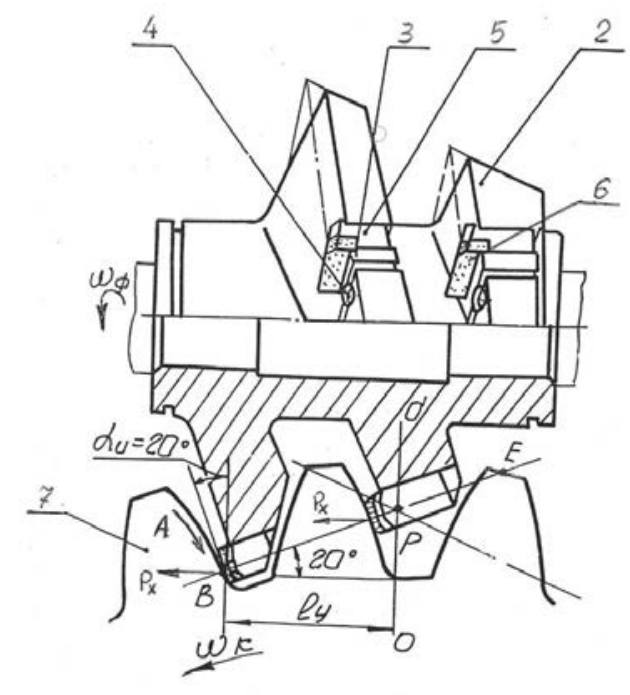

a

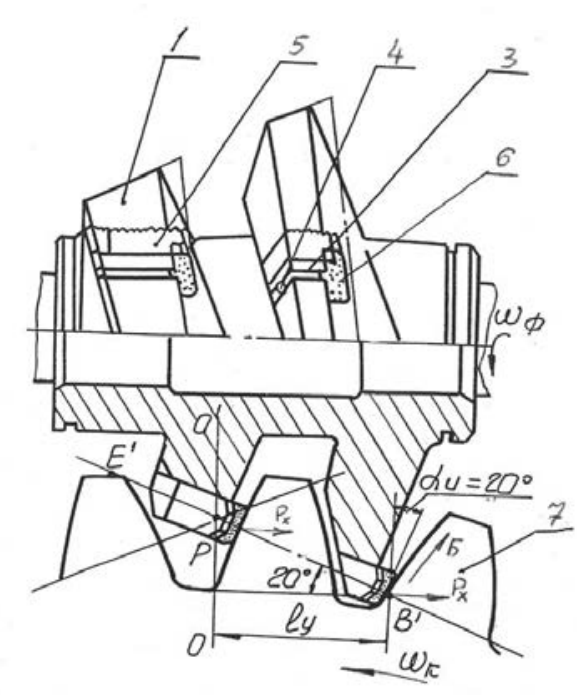

$b$

Fig. 4. Two-body universal single-sided milling cutter:

$a$-left housing assembly; $b$-right housing assembly (1-right housing; 2-left housing;

3-hard-alloy substrate; 4-screw for fixing the block 5; 5 - block for fixing the cutting blade; 6-cutting plate; 7 -cutting tooth)

Analysis of cutting schemes and kinematics of gear processing with universal double-body cutters (Shapovalov, V., 2009: 3; Mironenko, E., 2015: 30) shows that when the right body is working (Fig. 4, a), the axial cutting forces $P_{x}$ coincide with the direction of rotation of the processed wheel $\omega_{k}$ (with the direction of rotation of the dividing worm wheel of the machine), and the removal of the allowance goes sequentially from the base of the tooth to its top (arrow B). 
When removing the allowance in the direction of the arrow $B$ (Fig. $4, b$ ), the width of the layers cut by the teeth of the left housing, although not exceeding the nominal length of the cutting edge of $20 \mathrm{~mm}$, is still 2-2.5 times greater than that of the teeth of the right housing (Iurchyshyn, O., 2019; Klochko, A., 2020).

The placement of the carbide cutting elements of the cutter only along the lines of the machine engagement of the tool and the workpiece makes it more economical compared to the known designs of similar tools.

\section{Conclusions}

The developed technological studies of ensuring the quality of gear processing of large-module cylindrical wheels allowed us to solve the scientific and technical problem associated with the production of large-module gears with high-hardness teeth while improving the quality of their manufacture, reducing labor costs, and reducing material consumption.

The application of the developed technological methods of pre-blade processing of the teeth of hardened wheels with carbide cutters reduces the labor intensity of low-performance gear grinding operations, depending on the wheel module, by 3-4 times by reducing the allowance from $1.5-2.5 \mathrm{~mm}$ on the tooth side to $0.3-0.5 \mathrm{~mm}$, and also allows you to ensure the gear processing process is economical by reducing the consumption of carbide plates.

The obtained results of the research allow us in the long term:

- to develop a technological system for finishing gear milling of large-modulus hardened cylindrical gears instead of gear grinding for gears of accuracy degree 6B-8B (GOST1643-81), operating in wide speed ranges $(0.5-30 \mathrm{~m} / \mathrm{s})$, power $50-500000 \mathrm{~kW}$ wheel diameter $500-12000$ $\mathrm{mm}$, gear crown height up to $1200 \mathrm{~mm}$, module 12-65 $\mathrm{mm}$;

- develop special equipment to provide technological equipment for intensive and high-quality high-speed gear processing of large-modulus hardened cylindrical gears;

- to develop methods for modeling the relationship between the operational properties of the surfaces of large-modulus hardened cylindrical gears with quality indicators using graph theory, the choice and purpose of technological support for the system of parameters for assessing the impact of vibrations on the formation process, the criterion method for assessing the impact of thermal balance on the performance, accuracy and quality of the surface layer, which allows us to form a single technological approach for processing large-modulus hardened cylindrical gears.

\section{References}

Alaa, F. I. I., Akimov, O., Kostyk, K. (2017). Razrabotka kombinirovannoj tehnologii uprochneniya poverhnostnogo sloya stali 38H2MYuA [Development of a combined technology for strengthening the surface layer of steel 38X2MYA]. Vostochno-Evropejskij zhurnal peredovyh tehnologij, Vol. 2, no. 11(86). [in Ukrainian]

Artoni, A. (2019). A methodology for simulation-based, multiobjective gear design optimization. Mechanism and Machine Theory, no. 133, pp. 95-111. Retrieved from: https://www. sciencedirect.com/science/ article/abs/pii/S0094114X18307316

Czerniec, M., Kietbiński, J., \& Czerniec, J. (2019). Computer Simulation of the Impact of Optimization of Width in the Helical Cylindrical Gear on Bearing and Durability. Part 1. Height Correction of the Gear Profile. Advances in Science and Technology. Research Journal, Vol. 13, no. 1, pp. 52-59. [in Poland] 
Czerniec, M. (2019). Computer Simulation of the Impact of Optimization of Width in the Helical Cylindrical Gear on Bearing and Durability Part 1. Height Correction of the Gear Profile. Advances in Science and Technology. Research Journal, Vol. 13, no. 1. [in Poland]

Dhafer, W. A. R., Kostyk, V., Kostyk, K., Glotka, A., \& Chechel, M. (2016). The choice of the optimal temperature and time parameters of gas nitriding of steel. Vostochno-Evropejskij zhurnal peredovyh tehnologij, no. 3(5), pp. 44-50. [in Ukrainian]

Gasanov, M. I. (2018). Tverdosplavnye chervyachnye frezy posle almaznoj zatochki dlya vosstanovleniya krupnogabaritnyh zubchatyh koles [Carbide worm cutters after diamond sharpening for the restoration of large-sized gears]. Rezanie i instrumenty v tehnologicheskih sistemah: Mezhdunar. nauch.-tehn. sb., Kharkiv: NTU «KhPI». Int. 88, pp. 32-42. [in Ukrainian]

Gavranovic, S., Hartmann, D., \& Wever, U. (2019). Topology optimization using gpgpu. In Advances in Evolutionary and Deterministic Methods for Design, Optimization and Control in Engineering and Sciences, pp. 553-566. Springer, Cham. Retrieved from: https://link.springer. com/chapter/10.1007/978-3-319-89988-6_33

Gołębski, R., \& Ivandic, Z. (2018). Analysis of Modification of Spur Gear Profile. Tehnicki Vjesnik, no. 25(2), pp. 643-648. Retrieved from: https://hrcak.srce.hr/index.php? show=clanak\&id_clanak_jezik $=293228$

Iurchyshyn, O. Ya., Okhrimenko, O. A., Dmytro, O. R., Kostyk, K. O., \& Klochko, O. O. (2019). Morfolohichnyi analiz konstruktorsko-tekhnolohichnykh parametriv vysokotochnykh, vazhko navantazhenykh, velykohabarytnykh zubchatykh reiok vidpovidalnykh reikovykh peredach [Morphological analysis of design and technological parameters of high-precision, heavyloaded, large-sized gear racks of critical rack-and-pinion gears]. Nauka ta vyrobnytstvo, no. 21. Retrieved from: http://sap.pstu.edu/article/view/187603 [in Ukrainian]

Jian, K., Li-Ping, Z., \& Wen-Qiang, Y. (2013). Optimization Design of a Gear Profile Based on Governing Equations. Research Journal of Applied Sciences, Engineering and Technology, Vol. 5, no. 19, pp. 4780-4784.

Klochko, A. A., Skorkin, A. O., Kamchatnaya-Stepanova, E. V., Starchenko, E. P., \& Ishenko, M. G. (2020). Sovremennye metody tehnologii formoobrazovaniya krupnomodulnyh zubchatyh koles [Modern methods of forming technology of large-module gears]. Znanstvena misel, agricultural sciences, no. 48-1, pp. 25-29. [in Slovenia]

Kostyk, V. O., Kostyk, K. O., Kovalov, V. D., Turmanidze, R., \& Dašić, P. (2019, July). Increase of operational properties of tools and machine parts nitriding the powder mixture. In IOP Conference Series: Materials Science and Engineering, Vol. 568, no. 1, p. 012118. IOP Publishing. Kostyk, K.O. (2016). Poverkhneve dvosharove zmitsnennia stali pry poslidovnomu nasychenni vuhletsem ta borom $v$ poroshkovykh makro-ta nanodyspersnykh seredovyshchakh [Surface twolayer hardening of Steel under constant saturation with carbon and boron in powder macro and nanodisperse media]. Visnyk Natsionalnoho tekhnichnoho universytetu Kharkivskyi politekhnichnyi instytut. Seriia: Novi rishennia v suchasnykh tekhnolohiiakh, no. 42, pp. 54-63. [in Ukrainian]

Kostyk, K.O. (2015). Rozrobka tekhnolohii mistsevoho poverkhnevoho zmitsnennia zubchatoho tsylindrychnoho kolesa vidtsentrovanoho zmishuvacha [Development of technology for local surface hardening of the gear cylindrical wheel of a centrifugal mixer]. Novi materialy i tekhnolohii v metalurhii ta mashynobuduvanni, no. 2, pp. 39-43. [in Ukrainian]

Kostyuk, G. I., Popov, V. V., \& Kostyk, K. O. (2019). Konstruirovanie materiala rezhushego instrumenta s uchetom tipa uprochneniya nanopokrytij [Design of the cutting tool material taking into account the type of nanocoating hardening]. Tehnologicheskie sistemy, no. 87/2, pp. 25-37 [in Ukrainian] 
Masjedi, M., Khonsari. M.M. (2015). On the effect of surface roughness in point-contact EHL: formulas for film thickness and asperity load, Tribol. Int. 82, pp. 228-244. Retrieved from: https://www.sciencedirect.com/science/article/abs/pii/S0301679X1400334X

Mironenko, E. V., Klochko, A. A., Shapovalov, V. F., \& Chmyr, V. A. (2013). Sovershenstvovanie tehnologii zubonarezaniya chervyachnymi modulnymi frezami s kontaktnoreaktivnoj pajkoj rezhushih plastin [Improving the technology of gear cutting with worm modular cutters with contact-reactive soldering of cutting plates]. Nadezhnost instrumenta i optimizaciya tehnologicheskih sistem, Kramatorsk: DGMA, Int. 33, pp. 3-7. [in Ukrainian]

Mironenko, E. V., Shapovalov, V. F., Klochko, A. A., Palashek, S. Yu., \& Ostapovich, E. V. (2015). Konstruktorsko-tehnologicheskie sposoby povysheniya proizvoditelnosti i kachestva zuboobrabotki krupnogabaritnyh zubchatyh vencov [Design and technological methods for improving the productivity and quality of gear processing of large-sized gear rings] Visnyk NTU «KhPI». Seriia: Tekhnolohii v mashynobuduvanni. Kharkiv: NTU «KhPI», Vol. 4, no. 1113, pp. $28-32$. [in Ukrainian]

Mohammadkhani, R., Nemati, D., \& Babaei B. (2012). Optimizing Helical Gear Profile for Decreasing Gearbox Noise. Journal of Basic and Applied Research International, Vol. 2, pp. 6685-6693.

Nazapov, Yu. F., Ivanajskij, A. V., Svipidenko, D. S., \& Ppokofev, A. V. (2009). Nanotehnologiya mehanicheskoj obpabotki detalej mashin [Nanotechnology of mechanical processing of machine parts]. Tehnologiya mashinostroeniya, no. 6, pp. 9-10. [in Ukrainian]

Nechyporuk, M., \& Kostyk, K. (2020, March). Study of Ions Energy, Their Varieties and Charge on Temperature, Rate of Temperature Rise, Thermal Stresses for Nanostructures on Construction Materials. In Advanced Manufacturing Processes: Selected Papers from the Grabchenko's International Conference on Advanced Manufacturing Processes, Springer Nature. Odessa. p. 470. [in Ukrainian]

Permyakov, A. A., Yurchishin, O. Ya., Perminov, E. V., \& Shepelev, D. K. (2020). Innovacionnye tehnologicheskie napravleniya dlya obespecheniya stabilizacii processa obrabotki zubchatyh reek [Innovative technological directions for ensuring the stabilization of the gear rack processing process]. Visnyk NTU «KhPI». Seriia: Tekhnolohii v mashynobuduvanni. Kharkiv: $N T U$ «KhPI», no. 2, pp. 16-21. [in Ukrainian]

Popov, V., Kostyuk, G., Nechyporuk, M., \& Kostyk, K. (2019, September). Study of Ions Energy, Their Varieties and Charge on Temperature, Rate of Temperature Rise, Thermal Stresses for Nanostructures on Construction Materials. In Grabchenko's International Conference on Advanced Manufacturing Processes. Springer, Cham. pp. 470-477. Retrieved from: https:// link.springer.com/chapter/10.1007/978-3-030-40724-7_48. [in Ukrainian]

Shapovalov, V. F., Pechenyj, V. I., Korotun, A. N., Klochko, A. A., \& Mihajlov, G. I. (2009). O patriarhe zuboobrabotki ak. Sidorenko. [About the patriarch of dental treatment ak. Sidorenko]. Visnyk NTU «KhPI»: zb. nauk. pr. Tematychnyi vypusk: Problemy mekhanichnoho pryvodu. Kharkiv: NTU «KhPI», no. 20, pp. 3-7. [in Ukrainian]

Stokes, J. (2008). The theory and application of the HVOF thermal spray process. Dublin City University, Dublin, 206 p., pp. 1-14.

Suslov, A. G., Ryzhov, E. V., Suslov, A. G., \& Fyodorov, V. P. (2006). Tehnologicheskoe obespechenie i povyshenie ekspluatacionnyh svojstv detalej i ih soedinenij [Technological support and improvement of operational properties of parts and their connections]. Moskva: Mashinostroenie, 447 p. [in Russian]

Suslov, A. G., Fedorov, V. P., Nagorkin, M. N., \& Pyrikov, I. L. (2018). Kompleksnyj podhod k eksperimentalnym issledovaniyam tehnologicheskih sistem metalloobrabotki po obespecheniyu 
parametrov kachestva i ekspluatacionnyh svojstv poverhnostej detalej mashin [A comprehensive approach to experimental research of technological systems of metalworking to ensure the quality parameters and operational properties of the surfaces of machine parts]. Naukoemkie tehnologii v mashinostroenii, Vol. 10, pp. 3-13. [in Ukrainian]

Timofeev, Yu. V., Klochko, A. A., \& Shapovalov, V. F. (2010). Tehnologiya zubofrezerovaniya zakalennyh krupnomodulnyh koles specialnymi chervyachnymi frezami s minimiziruyushimi parametrami glavnyh rezhushih kromok [Technology of gear milling of hardened large-module wheels with special worm cutters with minimizing parameters of the main cutting edges]. Naukovi notatky: mizhvuz. zb, Lutsk, Int. 29, pp. 209-216. [in Ukrainian] 